\title{
POLITIK HUKUM DALAM BIDANG HUKUM KELUARGA ISLAM DI INDONESIA
}

\author{
FITRA MULYAWAN, KIKI YULINDA, DORA TIARA \\ Fakultas Hukum Universitas Ekasakti \\ fitramulyawan@gmail.com, kikiyulinda@gmail.com,doratiara@gmail.com
}

\begin{abstract}
In Indonesia, religion and state are two different entities, and each has its own autonomy, where there is an area that is completely "belonging to" religion, the state cannot enter it and there is also an area that is fully the competence of the state, so religion is not can participate in it. So that the formation of laws will reflect the configuration of power and political interests. In the actualization of political power and interests, sometimes there is a clash between the interests of fragmatism and those that are permanent and in favor of the benefit of mankind. This means that the interests of ideological values that live and develop in society can be configured with the interests of political power fragmatism. Therefore, first, the legislative program for several aspects of the modernization of Islamic family law politics in Indonesia, namely starting with the history of legislation on marriage in Indonesia, one of which is the Dutch East Indies Government circulating the Draft Ordinance on Registered Marriage, which includes the principle of monogamy and the prohibition of imposing divorce out of court. Then from the point of view of the meaning of the ideal law, the presence of $\mathrm{KHI}$ is a series of historical national laws that can reveal the various meanings of the life of the Indonesian Muslim community. Second, before the birth of Law no. 1 of 1974 in Indonesia various marriage laws apply for various groups of citizens and various regions. in the Indieche Staats Regeling (ISR), namely the Indian constitutional regulations. After independence, the Indonesian government has established a number of Islamic marriage regulations. Among them are Law Number 22 Year 1946 concerning Registration of Marriage, Divorce and Reconciliation.
\end{abstract}

Keywords: Political Law. Islamic family, Indonesia.

Abstrak: Di Indonesia, agama dan negara adalah dua entitas yang berbeda, dan masing-masing memiliki otonominya sendiri, di mana ada wilayah yang sepenuhnya "milik" agama, negara tidak mungkin memasukinya dan ada pula wilayah yang sepenuhnya menjadi kompetensi negara, maka agama tidak dapat ikut di dalamnya. Sehingga pembentukan hukum akan mencerminkan konfigurasi kekuatan dan kepentingan politik. Dalam aktualisasi kekuatan dan kepentingan politik ini terkadang terjadi benturan antara kepentingan fragmatisme dengan kepentingan yang bersifat permanen dan berpihak pada kemaslahatan umat manusia. Artinya, kepentingan nilainilai ideologi yang hidup dan berkembang di tengah masyarakat dapat dikonfigurasi dengan kepentingan fragmatisme kekuatan politik. Oleh karena itu pertama, program legislasi beberapa aspek modernisasi politik hukum keluarga Islam di Indonesia yaitu dimulai dengan sejarah legislasi Undang-undang perkawinan di Indonesia salah satunya adalah Pemerintah Hindia Belanda mengedarkan Rancangan Ordonansi Perkawinan Tercatat, yang isinya antara lain menganut prinsip monogami dan tidak boleh menjatuhkan talak di luar pengadilan. Kemudian Dari sudut lingkup makna the ideal law, kehadiran KHI merupakan rangkaian sejarah hukum nasional yang dapat mengungkapkan ragam makna kehidupan masyarakat Islam Indonesia. Kedua, Sebelum lahirnya Undang-Undang No. 1 Tahun 1974 di Indonesia berlaku berbagai hukum perkawinan bagi berbagai golongan warga negara dan berbagai daerah. di 
dalam Indieche Staats Regeling (ISR) yaitu peraturan Ketatanegaraan Hindia. Setelah merdeka, pemerintah membentuk sejumlah peraturan perkawinan Islam. Di antaranya Undang-undang Nomor 22 Tahun 1946 tentang Pencatatan Nikah, Talak, dan Rujuk.

Kata Kunci: Politik Hukum. Keluarga Islam, Indonesia.

\section{A. Pendahuluan}

Tidak dapat dipungkiri bahwa hukum merupakan instrumentasi keputusan politik, sehingga pembentukan hukum akan mencerminkan konfigurasi kekuatan dan kepentingan politik. Dalam aktualisasi kekuatan dan kepentingan politik ini terkadang terjadi benturan antara kepentingan fragmatisme dengan kepentingan yang bersifat permanen dan berpihak pada kemaslahatan umat manusia. Pada satu sisi, kepentingan fragmatisme akan cenderung mengabaikan nilai-nilai yang tumbuh dan berkembang di tengah masyarakat, dan di sisi lain kepentingan yang bersifat permanen "termarginal" oleh isu-isu modernisasi, globalisasi dan memetakannya ke dalam watak kehidupan tradisional yang dikonotasikan dengan ketinggalan zaman. Padahal keduanya dapat diintegrasikan dalam satu pola yang saling melengkapi dan berkontribusi. Artinya, kepentingan nilai-nilai ideologi yang hidup dan berkembang di tengah masyarakat dapat dikonfigurasi dengan kepentingan fragmatisme kekuatan politik.

Di tengah-tengah sebuah masyarakat, pasti ada hukum yang dipakai untuk mengatur tingkah laku agar terpelihara ketertiban di dalamnya. Hal ini dinilai wajar, karena pada prinsipnya hukum sendiri bersifat mengatur dan memaksa (Kansil, 1989). Masalahnya, apakah aturan itu bersifat statis atau dinamis? Sedangkan masyarakat itu berkembang. Karena itu, hukum harus berkembang sesuai dengan perkembangan masyarakat. Secara normatif, hukum sendiri hanyalah benda mati. Hukum tidak hidup dan tidak dapat mengubah dirinya sendiri, sehingga jika tidak diubah dan dimodernisasi maka hukum itu tidak akan pernah berkembang.

Kaitannya dengan Indonesia, yang merupakan negara hukum dan masyarakatnya terus berkembang, hukum di Indonesia pun terus berkembang mengikuti dinamika dan konteks masyarakat. Sebagai negara yang berpenduduk mayoritas Muslim, nampaknya, berbagai perundang- undangan yang ada juga mengikuti dinamika dan perkembangan masyarakat Muslim. Di sini, hukum Islam berkonstribusi dalam pembangunan hukum nasional. Banyak kalangan berharap, hukum Islam dapat memberikan warna positif dalam reformasi hukum di Indonesia.Pembaruan hukum itu sendiri disesuaikan dengan perkembangan masyarakat yang dinamis. Dalam Islam dikenal ungkapan bahwa la yunkar taghayyur al-ahkam bi taghayyur al-azman (Azhari, 2015). Kaidah ini menjelaskan bahwa dengan berubahnya waktu dan tempat, hukum pun menghendaki perubahan, baik secara normatif atau praktis. Dalam satu waktu, sebuah aturan hukum disepakati dan dijadikan pedoman bagi masyarakat, tapi di lain waktu, mungkin aturan hukum itu dianggap tidak relevan, tidak patut dijadikan pedoman, dan tidak dipraktekan oleh masyarakat.

Perbedaan mendasar antara hukum positif dengan hukum Islam adalah bahwa hukum positif merupakan pernyataan kehendak manusia yang berhimpun dalam wadah bernama negara sehingga kepentingan fragmatis tidak dapat terelakkan. Sedangkan hukum Islam merupakan hukum ketuhanan, sehingga nilai-nilai ideologi yang hidup dan berkembang di tengah masyarakat akan senantiasa mendapat ruang dan tempat untuk dikembangkan dan dilestarikan. Di negara-negara di mana Islam berpengaruh kuat, hukumnya juga akan banyak dipengaruhi oleh hukum Islam. Semula di dunia 
Islam, banyak persesuaian antara syar ${ }^{\text {re }}$ dan qanun. Ketegangan antara keduanya muncul akibat pengaruh Barat melalui kolonialismenya, yang mengakibatkan penggantian hukum di berbagai negara Muslim dengan hukum Eropa. Ketika masyarakat muslim berkesempatan membina hukumnya sendiri, mereka kembali menjadikan hukum Islam sebagai sumber penting legislasi. Demikian pula adanya yang terjadi dalam lintas sejarah legislasi hukum Islam di Indonesia.

Di Indonesia, agama dan negara adalah dua entitas yang berbeda, dan masingmasing memiliki otonominya sendiri, di mana ada wilayah yang sepenuhnya "milik" agama, negara tidak mungkin memasukinya dan ada pula wilayah yang sepenuhnya menjadi kompetensi negara, maka agama tidak dapat ikut di dalamnya. Dalam lintas sejarah pembangunan hukum Islam di Indonesia terukir konfigurasi yang saling menunjang antara kewenangan negara dengan ruang lingkup agama Islam, sehingga pola ini menjadi keran yang membuka jalan untuk mengalirnya proses legislasi hukum Islam di Indonesia, seperti masalah perkawinan, kewarisan, dan perwakafan sebagaimana yang dibukukan dalam Kompilasi Hukum Islam (KHI), serta beberapa peraturan perundang-undangan lainnya (Fuad, 2005).

Adanya persinggungan antara 'kepentingan negara dengan kewenangan Islam' serta 'kepentingan Islam dengan kewenangan negara' membuka mata umat muslim Indonesia bahwa sesungguhnya masyarakat Islam "beragama dalam berbangsa" dan "berbangsa dalam beragama". Dengan demikian, umat Islam harus menyadari dengan konkrit bahwa Islam tumbuh dan berkembang dari darah dan dagingnya sejarah yang aktual dan tidak lepas dari tangung jawab negara di dalamnya. Dalam konteks memahami kenyataan pola pembentukan hukum Islam di Indonesia khusunya proses penyusunan KHI, umat Islam harus menerima produksi sejarah yang melukiskan bahwa di dalam proses pembukuan KHI tersebut banyak terjadi perbedaan dan bahkan terkadang pertentangan antara ulama yang telah terkontaminasi dengan modernisasi dengan ulama-ulama tradisional yang masih berpegang teguh pada pemikiran klasik yang bersumber dari kitab fikih ulama terdahulu. Kondisi tersebut harus diterima sebagai sebuah kenyataan, sehingga pada gilirannya generasi muslim akan tetap bercermin pada nilai-nilai perbedaan tersebut secara terukur dan terkontrol. Demikian pula keadaan tersebut menjadi tolak ukur dalam proses reintepretasi serta reaktualisasi norma-norma agama yang telah dibukukan dalam bentuk hukum Islam Formal seperti KHI. Oleh karena itu, proses reintepretasi serta reaktualisasi norma-norma hukum Islam melalui studi kritis maupun kajian akademik berdasarkan nilai-nilai yang tumbuh dan berkembang dalam masyarakat Islam dengan tetap berpegang teguh pada patron nash dan tidak menunjukkan pada kehendak yang kebablasan.

Atas dasar ini, efektivitas pemberlakuan hukum juga tergantung dinamika dan respon masyarakat. Sebuah aturan normatif akan terealisasi dengan baik ketika respon masyarakat baik. Sebaliknya, sebuah aturan hanya akan berada di atas kertas, ketika respon masyarakat buruk, yang dalam tingkat tertentu, memungkinkan masyarakat tidak mematuhi aturan tersebut. Hal ini sesuai dengan konteks Indonesia, sebuah negara yang telah melakukan pembaruan dalam hukum keluarga Islam (Summa, 2005). Secara historis, pembaruan hukum perkawinan Islam di Indonesia dapat dibagi dalam tiga periode yaitu (Nasution, 2009): (1) pra penjajajahan; (2) masa penjajahan; dan (3) masa kemerdekaan (masa orde lama, orde baru, dan masa reformasi). Dalam masing-masing periode ini, hukum keluarga Islam mengalami perubahan dan pembaruan.

Namun, pada kenyataannya, perubahan dan pembaruan itu tidak selalu bermakna positif bagi masyarakat. Pemberlakuan, perubahan dan pembaruan itu memunculkan E-ISSN: 2657-0300 Lembaga Penelitian dan Penerbitan Hasil Penelitian Ensiklopedia 113 
berbagai macam tanggapan dari masyarakat. Masyarakat terpecah menjadi dua, yaitu: ada masyarakat Muslim yang menerima dan melaksanakan hukum itu, ada pula masyarakat Muslim yang menolak adanya pemberlakuan dan pembaruan tersebut.

\section{B. Metode Penelitian}

Tulisan ini menggunakan metode penelitiah yuridis normatif. Tulisan ini diharapkan dapat memperkaya khasanah ilmu pengetahuan serta dapat dan bisa memeberikan manfaat baik untuk perguruan tinggi maupun bagi dunia ilmu pengetahuan pada umumnya. walaupun tulisan ini tidak dapat menguraikan secara lengkap dan detail setiap rincian politik hukum dalam bidang keluarga Islam. Berdasarkan uraian di atas, maka dapat dirumuskan masalah pokok dalam tulisan ini yaitu bagaimana pelaksanaan legislasi hukum Islam di bidang hukum keluarga di Indonesia?. Untuk memberikan gambaran kajian ini secara rinci, maka masalah pokok tersebut akan diuraikan dalam beberapa sub masalah sebagai yaitu: 1) Bagaimana program legislasi beberapa aspek modernisasi politik hukum keluarga Islam di Indonesia? 2) Bagaimana hukum keluarga Islam sebelum Undang-Undang Nomor 1 Tahun 1974?

\section{Hasil dan Pembahasan}

\section{Program Legislasi Beberapa Aspek Modernisasi Politik Hukum Keluarga Islam di Indonesia}

\section{Sejarah dan Dinamika Legislasi Undang-Undang Perkawinan di Indonesia}

Sebelum Belanda masuk ke Nusantara, yaitu pada masa kerajaan- kerajaan Hindu-Budha dan Islam, khusus di wilayah kerajaan Islam sudah diterapkan dan dikembangkan hukum Islam untuk mengatur kehidupan di lingkungan masyarakat Islam waktu itu. Dalam mengahadapi persoalan- persoalan yang muncul di kalangan masyarakat Muslim, termasuk juga urusan perkawinan dan perceraian, masyarakat telah mempercayakan penyelesaiannya kepada orang khusus yang ahli dalam bidang agama Islam. Para ahli ini menggunakan konsep-konsep kitab fiqih konvensional dalam membuat aturan tentang hukum perkawinan.

Ketika orang-orang Belanda menginjakkan kakinya di Nusantara dan berhasil menguasainya mereka mengambil alih posisi superiordinasi dan memperlakukan pribumi yang mayoritas Muslim pada posisi subordinasi karena menjadi pihak yang terdesak oleh Belanda (Tendi, 2016). Salah satu kebijakan politik Belanda pada waktu itu ialah merubah hukum tentang perkawinan yang belaku bagi Muslim dengan Compendium Freijer, yaitu sebuah kitab hukum yang berisi aturan-aturan hukum perkawinan dan hukum kewarisan Islam. Kitab ini disusun oleh D.W. Friejer yang telah direvisi dan disempurnakan oleh para penghulu, pada tanggal 3 Agustus 1828, Compendium Freijer dicabut dan dinyatakan tidak berlaku lagi sehingga aturan perkawinan diserahkan kepada hukum adat, kecuali bagi kalangan tertentu (Tendi, 2016).

Pada tahun 1919, diberlakukan Indische Staatsregeling, yang merupakan UUD Hindia Belanda yang baru dan menganut asas hukum adat. Dalam hal ini dijelaskan bahwa perkara yang terjadi antara orang-orang Islam, diadili oleh Pengadilan Agama Islam atau kepala adat, kecuali UU menetapkan lain. Dengan demikian, UUD Hindia Belanda ketika itu menganut "asas hukum adat". Pada Juli 1937, Pemerintah Hindia Belanda mengedarkan Rancangan 
Ordonansi Perkawinan Tercatat, yang isinya antara lain menganut prinsip monogami dan tidak boleh menjatuhkan talak di luar pengadilan. Rancangan ini mendapat respon negatif dari kelompok muslim, yang mendukung hanyalah wanita terpelajar yang jumlahnya tidak banyak. Akhirnya rancangan ini dicabut. Rancangan tersebut kemungkinan besar merupakan respon pemerintah Hindia Belanda terhadap tuntutan sejumlah organisasi perempuan, di mana pada tahun 1928, di Indonesia digelar Kongres Wanita Indonesia yang salah satu pembahasannya adalah mengenai keburukan-keburukan yang terjadi dalam perkawinan menurut Islam (konvensional), seperti poligami, perkawinan di bawah umur, kawin paksa, dan talak sewenang-wenang. Organisasi-organisasi perempuan ini menuntut lahirnya UU perkawinan.

Jauh sebelumnya itu, RA Kartini (1879-1904) di Jawa Tengah dan Rohana Kudus di Minangkabau, telah lama mengkritik keburukan-keburukan yang diakibatkan oleh perkawinan yang saat itu terjadi. Pada kasus yang lebih khusus, tentang poligami, beberapa organisasi perempuan (Puteri Indonesia, Persaudaraan Isteri, Persatuan Isteri, dan Wanita Sejati) pada tanggal 13 Oktober 1929 berkumpul di Bandung dan membuat ketetapan tentang larangan poligami. Selanjutnya pada bulan Juni 1931 di Jakarta, Kongres Isteri Sedar memperkuat resolusi larangan poligami ini. Lain halnya, di kalangan perempuan juga terdapat organisasi perempuan lain yang menolak resolusi tersebut. Organisasi perempuan yang dimaksud seperti Sarekat Isteri Jakarta pada pertemuannya di Jakarta 1 minggu setelah kongres Isteri Sedar memberikan tanggapan negatif terhadap larangan tersebut. Sarekat Isteri Jakarta memprotes keputusan resolusi larangan poligami. Demikian juga Ratna Sari, Ketua Persatuan Muslim Indonesia (Permi) yang meyampaikan penolakannya atas larangan poligami pada kongres seluruh Wanita Indonesia di Jakarta tahun 1935.

Meskipun demikian, Pemerintah Hindia Belanda meresponnya dengan memunculkan Rancangan Ordonansi Perkawinan Tercatat yang di antara isinya menganut prinsip monogami serta tidak boleh menjatuhkan talak di luar pengadilan. Namun sebelum diberlakukan, rancangan ini mendapatkan penolakan keras dari umat Islam, yang diawali oleh NU dan Partai Syarikat Islam Indonesia, lalu disusul oleh pergerakan Islam lain, termasuk kalangan perempuan sebagaimana tersebut di atas. Akhirnya rancangan tersebut dicabut kembali. Pada masa awal kemerdekaan, ada upaya dari pemerintah untuk menasionalisasikan produk hukum warisan pemerintah Hindia Belanda. Hal ini terbukti dengan diterbitkan UU No. 22 Tahun 1946 tentang pencatatan nikah, talak dan rujuk yang merupakan penyatuan dari seluruh stbl. tentang pencatatan nikah, talak, dan rujuk yang ada sebelumnya. UU ini hanya berlaku untuk wilayah Jawa dan Madura, yang kemudian diperluas berlakunya untuk seluruh Indonesia dengan diberlakukannya UU No. 32 tahun 1954 tentang Penetapan berlakunya Undang-Undang Republik Indonesia Tanggal 21 November 1946 Nomor 22 Tahun 1946 tentang Pencatatan Nikah; Talak dan Rujuk diseluruh Daerah luar Jawa dan Madura (Aulawi, 1996). Isi UU No. 22 Tahun 1946 terdiri dari 7 pasal yang secara umum hanya memuat dua hal. Pertama, keharusan pencatatan perkawinan, perceraian dan rujuk. Kedua, penetapan pegawai yang ditugasi melakukan pencatatan, perceraian dan rujuk (Aulawi, 1996).

Kemudian pada tahun 1974 lahirlah UU No. 1 tahun 1974, yaitu UU pertama yang berisi materi perkawinan. Meskipun baru ada tahun 1974, tapi masyarakat telah lama menginginkannya, misalnya organisasi-organisasi wanita yang sampai membicarakannya di Dewan Rakyat (Volkskraad). Sebelumnya ada RA. Kartini dan E-ISSN: 2657-0300 Lembaga Penelitian dan Penerbitan Hasil Penelitian Ensiklopedia $\quad 115$ P-ISSN: 2657-0319 
Rohana kudus yang mengkritik perkawinan di bawah umur, perkawinan paksa, poligami dan talak. Ada juga kerjasama antara puteri Indonesia dengan Persaudaraan isteri, Persatuan Isteri dan Wanita Sejati di Bandung 13 oktober 1929 yang membicarakan tentang poligami dan pelacuran. Tahun 1931 Kongres Isteri sedar sejalan dengan itu. Selanjutnya 1950 lahir BPS (Badan Panasehat Pambinaan dan Pelestarian Perkawinan) yang didorong karena praktek perkawinan di bawah umur, talak semena-mena, poligami tidak bertanggung jawab. Sebagai respon positif tuntutan tersebut disusun dalam RUU meski tidak sampai diajukan ke DPR dikarenakan DPR beku karena Dekrit 5 juli 1959.

Pada masa orde baru, peraturan perundang-undangan merupakan kelanjutan dari usaha Orde Lama. Pada tahun 1966 sebagaimana TAP MPRS No. XXVIII/MPRS/1966 dalam pasal 1 ayat (3) bahwa perlu segera diadakan UU tentang Perkawinan. Tahun 1967 dan 1968 sebagai respon terhadap TAP MPRS tersebut, pemerintah menyampaikan dua RUU kepada DPR Gotong Royong yaitu; pertama, RUU tentang Pernikahan umat Islam. Kedua, RUU tentang ketentuan Pokok Perkawinan. RUU ini tidak mendapat persetujuan DPR (1 fraksi menolak, 2 abstain, 13 menerima), kemudian pemerintah menarik RUU tersebut. Pada awal 1967 Menteri Agama KH. Moh. Dahlan menyampaikan kembali RUU pernikahan umat Islam untuk dibahas di Dewan, ini kembali gagal disahkan (DPR tidak bergairah membahas karena penyusunannya didasarkan berbagai pandangan). Sementara itu, karena organisasi masyarakat semakin mendesak, akhirnya pemerintah menyiapkan RUU baru tanggal 31 juli 1973, yang terdiri dari 15 bab 73 pasal. RUU ini bertujuan; pertama, memberikan kepastian hukum bagi masalah perkawinan sebab sebelum ada UU Perkawinan hanya bersifat judge made law. Kedua, melindungi hak dan keinginan/harapan wanita. Ketiga, menciptakan UU yang sesuai dengan tuntutan zaman. Di samping tuntutan-tuntutan tersebut ada pula tanggapan negatif dari berbagai organisasi misalnya Sarekat Isteri Jakarta, dan Ratna Sari Ketua Persatuan Muslim Indonesia.

Perlu dicatat ketika munculnya UU No. 1 tahun 1974 tentang Perkawinan yaitu; pertama, muncul penolakan terhadap RUU Perkawinan ada hubungannya dengan kebijaksanaan pemerintah Hindia Belanda yang mengebiri hukum Islam dari otoritas Peradilan agama. Kedua, UU No. 1 tahun 1974 tentang perkawinan pertama lahir di masa orde baru yang merupakan respon terhadap tuntutan lahirnya UU di masa orde lama. UU No. 1 tahun 1974 merupakan kelanjutan UU No. 22 tahun 1946. Adapun isi UU No. 1 tahun 1974 yang berlaku secara efektif sejak 1 oktober 1975 terdiri dari 14 bab dan 67 pasal. Kemudian pada tahun 1989, lahir UU No. 7 tahun 1989 tentang Peradilan Agama. Tahun 1990 keluar PP No. 45 yang berisi perubahan PP No. 10 tahun 1983. Tahun 1991 berhasil disusun KHI mengenai perkawinan, pewarisan dan perwakafan berlaku dengan Inpres No. 1 tahun 1991.

\section{Dinamika Legislasi Hukum Keluarga Islam Berdasarkan Kompilasi Hukum Islam}

Sejarah legislasi hukum Islam di Indonesia sebenarnya dapat diketahui mulai dari masuknya Islam ke nusantara, secara sosiologis dan kultural, hukum Islam telah menyatu dan menjadi hukum yang hidup di tengah masyarakat. Akulturasinya dengan tradisi terkadang melahirkan sikap ekstrim dibeberapa daerah, seperti Aceh, Sulawesi Selatan, Riau dan Minangkabau, hukum Islam diterima tanpa reserve, sederajat dengan 
hukum adat setempat, hal ini dapat dibuktikan dengan adanya pepatah yang mengatakan Adat basandi syara', syara' basandi kitabbulah dan syara' mengato, adat mamakai, yang keduanya merefleksikan bagaimana kental dan menyatunya hubungan antara hukum Islam dengan adat setempat. Sifat fleksibel dan elastis yang dimiliki hukum islam inilah yang sebenarnya memungkinkan semuanya terjadi, termasuk proses melakukan legislasi hukum Islam di bidang hukum keluarga.

Dinamika secara umum di atas tergambar secara jelas dalam proses pelaksanaan legislasi hukum Islam di bidang hukum keluarga yang terjadi di Indonesia selama ini. Salah satu diantaranya adalah dinamika legislasi hukum Islam yang tergambar dalam sejarah lahirnya Instruksi Presiden Republik Indonesia Nomor 1 Tahun 1991 tentang Kompilasi Hukum Islam. Dari sudut lingkup makna the ideal law, kehadiran KHI merupakan rangkaian sejarah hukum nasional yang dapat mengungkapkan ragam makna kehidupan masyarakat Islam Indonesia, terutama tentang : (1) adanya norma hukum yang hidup dan ikut serta bahkan mengatur interaksi sosial, (2) aktualnya dimensi normatif akibat terjadinya ekplanasi fungsional ajaran Islam yang mendorong terpenuhinya tuntutan kebutuhan hukum, (3) responsi struktural yang dini melahirkan rangsangan KHI, dan (4) Alim Ulama Indonesia mengantisipasi ketiga hal di atas dengan kesepakatan bahwa KHI adalah rumusan tertulis hukum Islam yang hidup seiring dengan kondisi hukum dan masyarakat Indonesia (Bisri, 1999).

Sekurang-kurangnya tiga (3) hal yang dapat diketahui dari Inpres No 1 Tahun 1991 dan Keputusan Menteri Agama Nomor 154 Tahun 1991, yakni : (1) Perintah menyebarluaskan KHI tidak lain daripada kewajiban masyarakat Islam dalam rangka memfungsionalisasikan eksplanasi ajaran Islam sepanjang yang normatif sebagai hukum yang hidup, (2) Rumusan hukum dalam KHI berupaya mengakhiri persepsi ganda dari keberlakuan hukum Islam yang ditunjuk oleh Pasal 2 ayat 1 serta 2 UU Nomor 1 Tahun 1974, segi hukum formal di dalam Undang-Undang nomor 7 Tahun 1989 sebagai hukum yang diberlakukan secara sempurna, (3) menunjukkan secara tegas wilayah berlaku pada instansi pemerintah dan masyarakat yang memerlukannya. Ketiga hal tersebut bukan saja menunjukkan pentingnya penyebarluasan KHI, tetapi justeru presentasi hukum perkawinan, kewarisan dan wakaf dari KHI menjadi sebuah fenomena sejarah hukum terhadap eksistensi teori hukum yang menyinggung hukum Islam. Masih dijumpai kelompok masyarakat Islam yang menempatkan hukum Islam yang tertulis dalam kitab-kitab fikih sebagai sesuatu yang sakral akibat kedudukannya sebagai bagian dari ajaran Islam. Ia bersama hukum produk legislatif nasional ikut serta dan mengatur interaksi sosial, tetapi di tengah kebersamaan demikian, nilai sakral yang dilekatkan pada hukum Islam menjadi hambatan peletakkan hukum produk legislatif nasional pada kedudukannya yang sederajat dengannya, sekalipun ajaran Islam telah tertransformasi secara formal ke dalamnya (Abdullah, 1994).

KHI disusun atas prakarsa penguasa negara dalam hal ini ketua Mahkamah Agung dan Menteri Agama (melalui SKB) dan mendapat pengakuan ulama dari berbagai unsur. Secara resmi KHI merupakan hasil konsensus (ijma') ulama dari berbagai golongan melalui media lokakarya yang dilaksanakan secara nasional yang kemudian mendapat legalisasi dari kekuasaan negara yaitu Presiden. Penyusunan KHI dapat dipandang sebagai suatu proses transformasi hukum Islam dalam bentuk tidak tertulis ke dalam peraturan perundang-undangan. Dalam penyusunannya dapat dirinci pada dua tahapan, yaitu Pertama tahapan pengumpulan bahan baku yang digali dari berbagai sumber baik tertulis maupun tidak tertulis. Kedua, tahapan perumusan yang didasarkan kepada peraturan perundang-undangan yang berlaku dan sumber hukum 
Islam (al-Qur'an dan Sunnah Rasul) khususnya ayat dan teks yang berhubungan dengan substansi KHI (Bisri, 1999).

Berkenaan dengan kedudukan KHI dalam sistem hukum nasional, hal tersebut diukur oleh unsur-unsur sistem hukum nasional sebagaimana telah dikemukakan. Pertama, landasan ideal dan konstitusional KHI adalah Pancasila dan UUD 1945. Hal itu dimuat dalam konsideran Inpres dan dalam penjelasan Umum KHI. Ia disusun sebagai bagian dari sistem hukum nasional yang menjamin kelangsungan hidup beragama berdasarkan Ketuhanan Yang Maha Esa yang sekaligus merupakan perwujudan kesadaran hukum masyarakat dan bangsa Indonesia. Kedua, ia dilegalisasi oleh instrumen hukum dalam bentuk Inpres yang dilakukan oleh keputusan Menteri Agama, yang merupakan bagian dari rangkaian peraturan perundang-undangan yang berlaku. Ketiga, ia dirumuskan dari tatanan hukum Islam yang bersumber dari alQur'an dan Sunnah Rasul. Hal itu yang menjadi inti hukum Islam yang mencakup berbagai dimensi: syari'ah, fiqih, fatwa, qanun, idarah, qadha, dan adat. Ia merupakan perwujudan hukum Islam yang bercorak keindonesiaan. Keempat, saluran dalam aktualisasi KHI antara lain pengadilan dalam lingkungan peradilan agama, sebagaimana dapat ditafsirkan secara teologis dari penjelasan umum KHI (Bisri, 1999).

Menurut Abdul Gani Abdullah, dilihat dari tata hukum nasional, KHI dihadapkan pada dua (2) pandangan: Pertama, sebagai hukum tidak tertulis seperti yang ditunjukkan oleh penggunaan instrmen hukum berupa Inpres yang tidak termasuk dalam rangkaian tata urutan peraturan perundangan yang menjadi sumber hukum tertulis. Kelemahan pandangan ini terletak pada pengabdian terhadap beberapa sumber pengambilan bagi penyusunan buku I, II dan III KHI yang terdiri dari Undang-Undang Nomor 22 tahun 1946 jo UU Nomor 32 Tahun 1954. UU nomor 1 Tahun 1974 jo PP Nomor 9 Tahun 1975, PP Nomor 28 tahun 1977. Sumber-sumber tersebut yang justeru mengakrabkan KHI menjadi hukum tertulis. Buku II cenderung mendukung pendapat ini sekalipun dalam kenyatannya ia juga disusun dengan mengambil kaidah hukum dari yurisprodensi Indonesia sepanjang mengenai kewarisan Islam. Kedua, KHI dapat dikategorikan sebagai hukum tertulis. Sumber yang ditunjukkan sebagaimana tersebut di atas menunjukkan KHI berisi law dan rule yang pada gilirannya terangkat menjadi law dengan potensi political power. Inpres nomor 1 tahun 1991 dipandang sebagai salah satu produk political power yang mengalirkan KHI dalam jajaran law. Melalui Inpres Nomor 1 tahun 1991 pada saatnya akan membuktikan bahwa manusia dipandang mampu mengantisipasi kebutuhan hukumnya seperti dalam semboyan The living law dari pada sekedar mengklaim adanya the ideal law tanpa akhir.

Dilihat dari sejarah pembentukannya, KHI merupakan jalan pintas untuk mengisi kekosongan hukum materil di peradilan agama yang mengakibatkan disparitas putusanputusan pengadilan agama selama ini. Hal itu terjadi disebabkan tidak adanya kitab hukum yang positif dan unifikatif. Berpedoman pada ungkapan, "tak ada rotan, akarpun jadi”, maka selama belum diwujudkan cita-cita memiliki hukum positif undang-undang perdata Islam melalui jalur formal ketatanegaraan, untuk sementara cukupkan saja dalam bentuk kompilasi. Pengukuhan formalnya berupa Inpres, sedangkan pernyataan berlakunya dalam bentuk keputusan menteri agama nomor 154 tahun 1991. Terhadap kenyaan ini, bagi mereka yang bersikap kaku dan formalistis wujud kelahiran KHI dianggap kurang memenuhi syarat perundang-undangan. 
Akan tetapi bagi mereka yang berpandangan dari sudut sosiologis, tidak demikian halnya, karena menurut ajaran sosiologi hukum, hukum adalah kebutuhan masyarakat. Dalam satu ajaran hukum dipahami bahwa "hukum adalah pakaian masyarakat yang harus sesuai ukuran dan jahitannya dengan kebutuhan masyarakat". Jika ajaran ini dikaitkan dengan teori realisme atau teori fungsional tidak mesti suatu perangkat hukum harus dicipta secara kaku menurut hukum tata negara dalam bentuk undang-undang. Karena bukan hanya apa yang dirumuskan dalam bentuk undangundang yang bernilai sebagai hukum positif dan obyektif, akan tetapi suatu perangkat hukum yang dirumuskan dalam bentuk lain, asal nilai-nilainya benar-benar sesuai dengan kebutuhan masyarakat dan cocok pula untuk dipakai oleh masyarakat yang bersangkutan, mempunyai validitas dan otoritas sebagai hukum untuk mengayomi ketertiban hidup masyarakat.

Dengan demikian, meskipun bentuk formal KHI hanya didukung dalam bentuk Inpres, tidak mengurangi sifat legalitas dan otoritasnya. Karena segala yang dirumuskan di dalamnya benar-benar sangat dibutuhkan untuk ketertiban masyarakat Islam masa kini dan masa akan datang. Kandungan isinyapun secara sungguh-sungguh telah diupayakan agara benar-benar sesuai dengan keinginan dan kesadaran masyarakat pemakainya.

\section{Hukum Keluarga Islam Sebelum Undang-undang Nomor 1 Tahun 1974}

Catatan sejarah terbentuknya Undang-undang Perkawinan sesungguhnya terlahir karena adanya ketidak puasan terhadap setiap sistem hukum yang ada, dimana setiap golongan maupun unsur-unsur yang ada di Indonesia mulai sadar bahwa selama ini mereka telah dikotak-kotakkan dengan adanya sistem hukum peninggalan kolonial Belanda yang mana mereka ingin memisahkan setiap unsur dari masyarakat Indonesia. Sebelum lahirnya Undang-Undang No. 1 Tahun 1974 di Indonesia berlaku berbagai hukum perkawinan bagi berbagai golongan warga negara dan berbagai daerah. di dalam Indieche Staats Regeling (ISR) yaitu peraturan Ketatanegaraan Hindia Pasal 163 yang membedakan golongan penduduk dalam tiga macam di antaranya golongan Eropa (termasuk Jepang), golongan pribumi (Indonesia) dan golongan Timur Asing kecuali yang beragama Kristen. Adapun berbagai hukum perkawinan yang berlaku saat itu sebelum lahirnya Undang- Undang No. 1 Tahun 1974 bagi berbagai golongan warga negara dan berbagai daerah sebagai berikut :

a. Bagi orang-orang Indonesia asli yang beragama Islam berlaku hukum agama yang telah diresepsi ke dalam hukum adat. Pada umumnya bagi orang-orang Indonesia asli yang beragama Islam jika melaksanakan perkawinan berlaku ijab Kabul antara mempelai pria dengan wali dari mempelai wanita. Hal ini sebagaimana diatur dalam hukum Islam. dalam konteks ini merupakan budaya bagi orang Indonesia yang beragama Islam hingga sampai saat ini.

b. Bagi orang Indonesia asli lainnya berlaku hukum adat;

c. Bagi orang Indonesia asli yang beragama Kristen berlaku huwelijks Ordonnantie Christen Indonesia (HOCI) S. 1933 nomor 74. Namun aturan ini sudah di atur di dalam Undang-Undang No. Tahun 1974 sehingga sekarang tidak berlaku lagi;

d. Bagi orang-orang Timur Asing Cina dan warga negara Indonesia keturunan Cina berlaku ketentuan hukum dalam KUH Perdata dengan sedikit perubahan aturan ini sudah tidak berlaku semenjak dikeluarkannya Undang-Undang No. 1 Tahun 1974.

e. Bagi orang timur asing lainnya dan warga negara Indonesia keturunan asing lainnya berlaku hukum adat mereka. Jadi bagi keturunan India, Pakistan, Arab 
dan lain yang sama, berlaku hukum adat mereka masing-masing yang biasanya tidak terlepas dari agama dan kepercayaan yang dianutnya.

f. Bagi orang-orang Eropa dan warga negara Indonesia keturunan Eropa (Indo) dan yang disamkan dengan mereka, berlaku KUH Perdata, yaitu BurgerlijkWetboek (BW). Termasuk dalam golongan ini adalah orang Jepang atau orang-oran lain yang menganut asas-asas hukum keluarga yang sama dengan asas-asas hukum keluarga Belanda.

Setelah merdeka, pemerintah RI telah membentuk sejumlah peraturan perkawinan Islam. Di antaranya Undang-undang Nomor 22 Tahun 1946 tentang Pencatatan Nikah, Talak, dan Rujuk (Nasution, 2002). Undang-undang ini ditetapkan oleh Presiden Republik Indonesia pada tanggal 21 Nopember 1946, yang terdiri dari 7 pasal, yang isi ringkasnya sebagai berikut (Agama, 2003):

a. Pasal 1 ayat $1 \mathrm{~s} / \mathrm{d}$ ayat 6 , yang isinya diantaranya; Nikah yang dilakukan umat Islam diawasi oleh Pegawai Pencatat Nikah yang diangkat oleh menteri agam, Talak dan Rujuk diberitahukan kepada Pegawai pencatat Nikah, yang berhak mengadakan pengawasan Nikah, Talak dan Rujuk Pegawai yang ditunjuk Menteri Agama, bila PPN berhalangan dilakukan petugas yang ditunjuk, biaya Nikah, Talak dan Rujuk ditetapkan Menteri Agama.

b. Pasal 2 terdiri dari ayat $1 \mathrm{~s} / \mathrm{d} 3$, yang isinya diantaranya, PPN membuat catatan Nikah, Talaq dan Rujuk dan memberikan petikan catatan kepada yang berkepentingan.

c. Pasal 3 terdiri dari 5 ayat, isinya antaranya; sanksi orang yang melakukan nikah, talak dan rujuk yang tidak dibawah Pengawasan PPN, sanksi orang yang melakukan Nikah, Talak dan Rujuk padahal bukan petugas.

d. Pasal 4, isinya hal-hal yang boleh dihukum pada pasal 3 dipandang sebagai pelanggaran.

e. Pasal 5 isinya peraturan yang perlu untuk menjalankan undang-undang ditetapkan oleh Menteri Agama.

f. Pasal 6 terdiri 2 ayat, isinya nama undang-undang, dan berlaku untuk daerah luar Jawa dan Madura.

g. Pasal 7, isinya undang yang berlaku untuk Jawa dan Madura.

Sepintas dilihat pasal-pasal tersebut, dapat dikatakan bahwa ciri paling utama dari undang-undang ini adalah semangat baru pemerintah untuk memperbaiki keefektifan catatan perkawinan, perceraian, dan rujuk bagi seluruh rakyat Indonesia. Namun, meskipun menurut undang-undang tersebut pencatatan pekawinan mesti menetapkan keabsahan perkawinan sebelum akad nikah dilangsungkan, namun pengaruh utamanya lebih pada soal proses hukum, bukan kandungan hukum. Dengan kata lain, pemerinyah pada waktu itu sangat berhati-hati memperkenalkan perubahan substantif terhadap hukum perkawinan dan hanya memilih hal-hal yang berkaitan dengan aspek-aspek prosedural. Namun, undang-undang ini tidak efektif dalam pelaksanaannya. Ini disebabkan masih berkecamuknya perang kemerdekaan.

Undang-undang ini pertama-tama hanya berlaku untuk Jawa dan Madura, yaitu mulai 1 Februari 1947. Baru sesudah tahun 1954 undang-undang ini diberlakukan secara menyeluruh di Indonesia. Yaitu melalui Undang-undang no. 32 tahun 1954 Tentang Penetapan Berlakunya Undang-Undang Republik Indonesia Tanggal 21 
Nopember 1946 Nomor 22 Tahun 1946 Tentang Pencatatan Nikah, Talak dan Rujuk di Seluruh Daerah Jawa dan Madura. Undang-undang ini disahkan pada tanggal 26 Oktober 1954 oleh Presiden Soekarno dan terdiri dari 3 pasal, yang secara garis besar sebagai berikut:

a. Pasal 1, Undang-Undang RI tanggal 21 Nopember 1946 No. 22 tahun 1946 tentang Pencatatan Nikah, Talak dan Rujuk berlaku untuk seluruh daerah luar Jawa dan Madura.

b. Pasal 1 A, Perkataan Biskal-gripir hakim kepolisian yang tersebut dalam pasal 3 ayat 5 Undang-undang RI No. 22 Tahun 1946 diubah menjadi Panitera Pengadilan Negeri.

c. Pasal 2, Peraturan-peraturan yang perlu untuk melaksanakan apa yang tersebut dalam pasal 1 undang-undang ini ditetapkan oleh Menteri Agama.

d. Pasal 3, Undang-Undang ini mulai berlaku pada hari diundangkan.

Sebagaimana dijelaskan di atas, bahwa dua undang-undang tersebut lebih bersifat prosedural. Oleh karena itu, secara materiil masih belum ada ketetapan tentang hukum yang berlaku dalam bidang hukum perkawinan Islam di Indonesia. Oleh karena itu, untuk mensiasati kekosongan hukum terebut, maka ulama para menjadikan kitab-kitab kuning sebagai hukum materilnya. Pada tahun 1953, Departemen Agama menetapkan 13 kitab fikih yang dijadikan pedoman dalam memutuskan perkara di Pengadilan Agama. Tiga belas kitab tersebut adalah: a) al-Bajury; b) Fath al-Mu in; c) Sharqawy 'ala al-Tahrir; d) al-Mahally; e) Fath al-Wahhab; f) Tuhfah; g) Taghrib al-Mushtaq; h) Qawanin al-Shar'iyyah Uthman Ibn Yahya; i) Qawanin al-Shar iyyah Sadaqah Di'an; j) Shamsury fi al-Fara'id; k) Bughyat al-Mustarshidin; 1) al-Fiqh `ala Madhahib alArba'ah, dan n) Mughni al-Muhtaj (Mubarok, 2003).

\section{Penutup}

Program legislasi beberapa aspek modernisasi politik hukum keluarga Islam di Indonesia yaitu dimulai dengan sejarah legislasi Undang-undang perkawinan di Indonesia salah satunya adalah Pemerintah Hindia Belanda mengedarkan Rancangan Ordonansi Perkawinan Tercatat, yang isinya antara lain menganut prinsip monogami dan tidak boleh menjatuhkan talak di luar pengadilan. Kemudian Dari sudut lingkup makna the ideal law, kehadiran KHI merupakan rangkaian sejarah hukum nasional yang dapat mengungkapkan ragam makna kehidupan masyarakat Islam Indonesia. Sebelum lahirnya Undang-Undang No. 1 Tahun 1974 di Indonesia berlaku berbagai hukum perkawinan bagi berbagai golongan warga negara dan berbagai daerah. di dalam Indieche Staats Regeling (ISR) yaitu peraturan Ketatanegaraan Hindia. Setelah merdeka, pemerintah RI telah membentuk sejumlah peraturan perkawinan Islam. Di antaranya Undang-undang Nomor 22 Tahun 1946 tentang Pencatatan Nikah, Talak, dan Rujuk.

\section{Daftar Pustaka}

Abdul Gani Abdullah, Pengantar KHI dalam Tata Hukum Indonesia Cet. 1; Jakarta : Gema Insani Press, 1994.

A Wasit Aulawi, "Sejarah Perkembangan Hukum Islam di Indonesia" dalam Amrullah Ahmad (ed), Dimensi Hukum Islam dalam Sistem Hukum Nasional, Bandung: Gema Insani Press, 1996.

Cik Hasan Bisri, KHI dan Peradilan Agama dalam Sistem Hukum Nasional Cet. 1; Jakarta : Logos Wacana Ilmu, 1999. 
C.S.T. Kansil, Pengantar Ilmu Hukum dan Tata Hukum Indonesia, Jakarta: Balai Pustaka, 1989.

Departemen Agama, Pedoman Pencatat Nikah, Jakarta: Departemen Agama RI, 2003.

Fathurrahman Azhari, al-Qawaid al-Fiqhiyyah ,Banjarmasin: Lembaga Pengembangan Kualitas Umat, 2015.

Jaih Mubarok, Akar-akar RUU Perkawinan Tahun 1973 di Indonesia, Bandung: Program Pasca Sarjana IAIN Bandung, Vol. 1 No. 3, 2003.

Khairuddin Nasution, Status Wanita di Asia Tenggara: Studi Terhadap PerundangUndangan Perkawinan Muslim Kontemporer di Indonesia dan Malaysia, Jakarta: INIS, 2002.

Khairuddin Nasution, Hukum Perdata (Keluarga) Islam Indonesia dan Perbandingan Hukum Perkawinan di Dunia Islam, Yogyakarta: Academia \& Tazzafa, 2009.

Mahsun Fuad, Hukum Islam Indonesia-Dari Nalar Partispatoris Hingga Emansipatoris, Cet. 1 ; LkiS : Yogyakarta, 2005.

Muhammad Amin Summa, Hukum Keluarga Islam di Dunia Islam Jakarta: Raja Grafindo, 2005.

Tendi, "Islam dan Agama Lokal dalam Arus Perubahan Sosial", al-Tahrir: Jurnal Pemikiran Islam Vol. 16, No. 1, 2016. 